\title{
MANAGEMENT OF LITIGANTS' SATISFACTION IN THEIR QUALITY OF LEGAL SERVICES' CUSTOMERS PROVIDED BY THE COURTS
}

\author{
Ioana, HULPUȘ ${ }^{1}$, Emanoil, MUSCALU ${ }^{2}$ and Viorica, FALOBA ${ }^{3}$ \\ ${ }^{1}$ Lucian Blaga University of Sibiu, Romania, ioana@ hulpus.ro \\ ${ }^{2}$ Lucian Blaga University of Sibiu, Romania, emanoil.muscalu@ulbsibiu.ro, \\ ${ }^{3}$ Lucian Blaga University of Sibiu, Romania, viorica.faloba@ulbsibiu.ro
}

\begin{abstract}
The quality of public services provided by the courts became one of the most important objectives in all developed countries. According to the current requirements, organizations must respond more promptly to the society's needs and demands. The citizen / customer's position and role became essential taking into consideration these changes and reforms, the quality of legal services depends on the user's demands and expectations holding a strong subjective character. On the other hand, the quality does not apply solely to the final product, namely the court's decision, but to all related activities carried out during the whole process, the way the citizens perceive all the adjacent activities. In this context Quality Management must identify appropriate methods and techniques to manage the customer's approach in all its complexity, from the analysis of the importance of learning about their needs, their expectations, and factors influencing the perception to the measurement of the customer satisfaction and not least the management of it.
\end{abstract}

KEY WORDS: sustainable management, customer satisfaction, management satisfaction, quality, justice;

\section{INTRODUCTORY CONSIDERATIONS:}

Quality resents those products or services that meet the users' expectations and of other stakeholders. When the organization providing the product or service is a public service the users and the stakeholders are the citizens. A citizen can be a particular service user but every citizen as taxpayer is a person interested in the services provided by the public institutions.

The legal system may be viewed as a process that converts incoming data (court actions, complaints, etc) to output data (court decision) completed by the human resources and material resources. The result or the final product defined by the output data it is designed for the user from outside the organization, legal services' customer.

The quality of the product or the service depends on the user's demands and expectations holding a strong subjective character. On the other hand, the quality does not apply solely to the final product, the court's decision, but to all related activities carried out during the entire process. Legal decision must meet also the terms of forms, legible and comprehensible, but also the terms of fund regarding the correct reasoning or the correct application of the law. Adjacent activities should be characterized by transparency, accessibility, promptly. The lack of a component deteriorates the final product's quality delivered to the society, under all the aspects.

For all these reasons, the considerations over the quality should be extended to all the activities that contribute to the best fulfilment of all the requirements and expectations and not just those relating to the basic product of the provided service.
Moreover, the quality of the provided service to the user is the result of the services chain of high quality continuously produced by the personnel and the organization's suppliers.

In terms of quality of justice, it is very important the user's perception about the product or service. Quality it is experienced when the perception of the service provided meets or exceeds expectations. We must accept that subjectivity plays an important role in perceiving a service provided.

For a fair assessment of the quality taking into account the level of customer satisfaction/citizens should not be taken into account only the quality of the service provided by the organization but also all the perceptions and expectations of users.

Analysing the legal system it is easily learned that there are great shortcomings, the quality it is not measured according the customer requirements. The legal system it is focuses on the law enforcement and establishing the legal order without worrying about identifying the participants' needs, desires and expectations. The remark made by the magistrates it is justified (Apostu F.), the main purpose of justice is not to record 100\% happy litigants but not offering a feedback will create a greater lack of confidence in legal system and thus to affect the service quality.

Applying in the field of justice the principle of focus on the customer, assumes following few steps:

- understanding the needs and expectations of litigants regarding the specific activities in the field of justice; 
- ensuring a balanced between the way of approaching the customers' needs and the one of the other stakeholders, organization's staff, local community, society in general;

- communicating these needs inside the organization, creating and strengthening an appropriate organizational culture;

- the management of the relationships with the litigants assuming knowledge of their needs and expectations, analysing their perception regarding the justice and its services, measuring their satisfaction and not least the management of satisfaction;

- periodical evaluation of customer to record the improvements;

\section{WHY CUSTOMER SATISFACTION IS IMPORTANT?}

The "new" public management pleads decisions' decentralization, adapting the services and responding to the citizen's needs and expectations and also to customize the public services and relations with the users as main objectives and in the same time reconciliation means between the public authorities and its users (Cluzel-Metayer, 2006).

According to Warin (1999), satisfaction of public service users becomes a selection of public performance indicator. This is a novelty for the public sector while measuring customer satisfaction has been for long time an element taken into consideration and put into practice by in the private sector.

The requirement of quality is now one of those "rules of conduct" that the public services can no longer ignore. The evolution of public sector on grounds of quality it is characterized by according an intense attention to the user satisfaction. As the public management specialists remark invoking public interest it is not enough to justify a public intervention. The reason of funding the organizations dealing with the customer's satisfaction it comes from the necessity of identifying, following and fulfilling the users' expectations.

Furthermore, it is considered that a public service it is not just a service provider, but also contributes to the society's cohesion. According to Chevallier (2005), "while the private organizations are withdrawn ", namely find their purpose in themselves, the public organizations are "extroverted", that serve to an interest above them.

Current requirements involve changing the role of the public sector and the citizen's profile change (more educated and more aware of its rights) which requires a public management based on effectiveness, efficiency, accountability, transparency, strategic approach and especially quality. Public manager has a direct responsibility towards the citizens and in the same time inside the private companies does not occur a similar relationship.

Christopher Pollitt and Geert Bouckaert described this tendency as a shift from the manufacturer's point of view, to the citizen / customer's point of view (Pollitt and Bouckaert, 1995)

The courts' presidents, from our point of view, have a greater responsibility to the citizen because of the judiciary organizations' specific purpose, namely the defense of legal order and of citizens' rights, having to achieve a real mission, accomplishment of the justice.

Judicial organizations should be more sensitive to the society's needs and expectations and the justice service's users. Legal organizations like all public sector institutions are the subject of reform process in order to provide better, faster and more numerous services. However, the quality, quantity and promptness are not the only requests that citizens demand from justice. As the haste with which the society changes it is increasingly higher, the judicial organizations should be able to respond to the needs by offering new solutions.

We emphasize that the reform of justice aims to restore confidence in the judicial system and its services. Judicial organizations should provide more space of choice, a high level of transparency by interacting with citizens / clients at all stages of policy development and service delivery. This approach does not mean, of course, that every time citizens / clients get what they want, as we have pointed out, justice cannot have $100 \%$ happy customers, while the courts activity mainly involves conflicting parties with different interests.

However, as the specialist in the field mention the successful organizations use the customer needs and expectations as a starting point, developing proposals according to them and meanwhile fulfilling the organizational requirements. Satisfaction is therefore linked to providing the services but also meeting the expectations and perceptions of citizens / customers. (Mungiu-Pupăzan, M.C., 2014)

\section{UNDERSTANDING THE CLIENTS/ CITIZENS' SATISFACTION}

Understanding and measuring the customer's satisfaction is a central preoccupation. Satisfaction is a widely concept, accepted despite the real difficulties of measuring and interpreting, that it is facing the typical approaches of its assessment. The most common approach is the use of general satisfaction surveys, conducted at every few years and designed to detect changes that occur in time, but there are also other methods. However the concept of satisfaction involves a serial of difficulties. (Communities Scotland Agency, 2006).

- It is not static, but changes over time; new experiences and levels of awareness will alter the potential levels of satisfaction that can be achieved.

- Can be complex and the result of experiences combination before, during and after the point at which they are measured.

- It takes place in different social contexts that can be unpredictable or inexpressible for the service user.

- The satisfaction grounds can be difficult to express, especially when taking into account less tangible aspects of services.

- Dissatisfaction reasons can be more easily expressed, especially if it is a state of exception.

If there are not understood the causes of satisfaction, there is the danger of treating a "good result" as a reason not to change anything, approaching it in a broad sense as a Public Relations tool. 


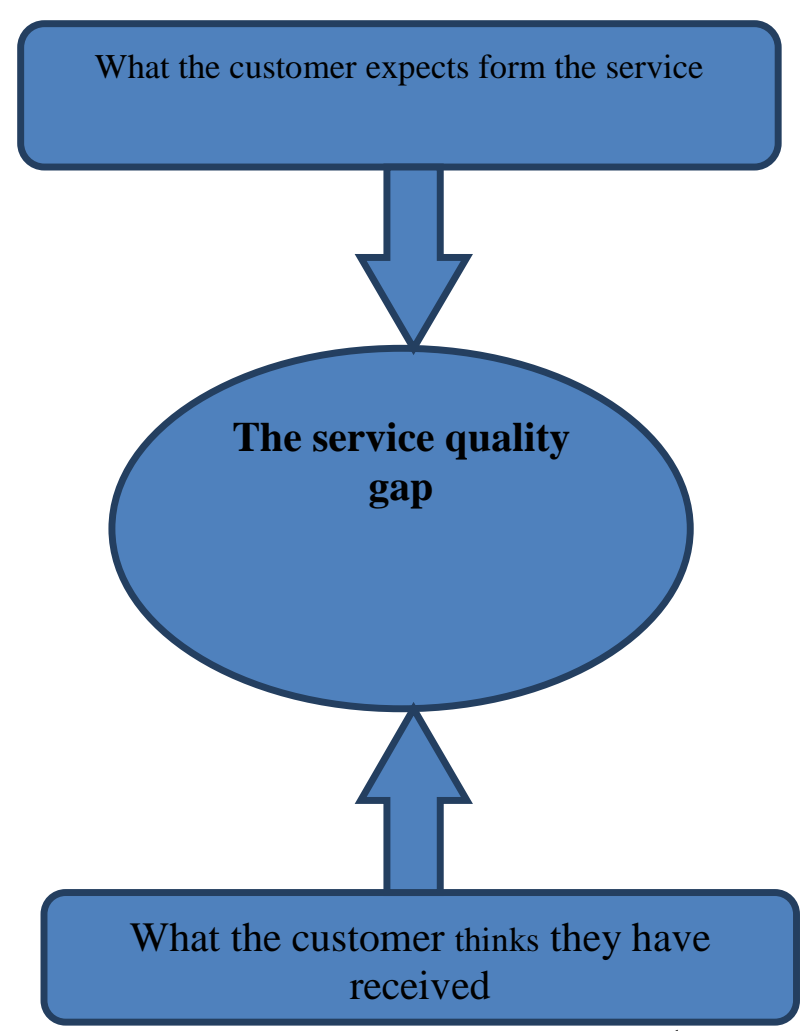

Figure 1. The Service Quality Dynamics ${ }^{1}$.

\section{FROM SATISFACTION MEASUREMENT TO SATISFACTION MANAGEMENT}

Measuring satisfaction based on expectations and the citizen's perceptions represents only one stage in the process of improving the quality on the principle of orienting toward the service's client.

Traditionally, the policy and management cycle it is dominated and controlled by politicians, administrators and in the case of judicial organizations by the judicial managers and the requirements of the law. In order to achieve the goals of quality and efficiency the citizens /customers should be getting more involved in this policy and management cycle at different levels (design, decision, implementation, monitoring and evaluation).

The citizen /customer must not appear in the frame only at the end, but must be present at all stages and steps of delivering the policies and services. Therefore, measuring the citizen's satisfaction /customer it is just a phase, the final phase. The contribution of citizens /customers with all their roles and at all the stages of the cycle must be taken into consideration. This can be defined as customer satisfaction management.

Organizations from the judiciary field are characterized by a greater rigidity; the principle of judicial independence ensures the absence of any interference in the work of courts artificially creating a barrier in the way of a beneficial cooperation between all the parties.

The Romanian judicial system suffers from a lack of external feedback from the litigants .Many Romanian magistrates strongly oppose to the idea of performance indicators based on external feedback. (F.Apostu, 2009)

As shown in the Report of the Working Group of the European Network of Councils for the Judiciary Quality Management, quality cannot be experienced in a court only linked to the users and other stakeholders' expectations.
Customer rating through dialogue, opinion polls is commonly used in most judicial systems in Europe. In Denmark the citizens, lawyers, prosecutors and other stakeholders are regularly questioned about their opinion about the courts activities. Thus during a specific period of one or two weeks individuals who come into contact with the court are asked to complete a questionnaire either on paper or electronically. The latest polls results were more than satisfactory, $91 \%$ of respondents were either satisfied or very satisfied with the work of the courts, the prestige of justice being obvious.

Belgium encourages the dialogue between the judiciary system and the litigants by organizing workshops / seminars but also by conducting a systematic survey of a public opinion for improving the quality and identifying some measuring tools of courts' efficiency.

Despite the efforts made by the Romanian judicial system in recent years to establish the standards for the judge profession, the public's confidence in justice has declined sharply. The magistrate's profile in Romania developed in 2006 and the Guide for the magistrate's assessment for the criteria: efficiency, integrity, quality and continuous training should be seen as laudable initiatives but insufficient without a reference to the perception level of the users and the society in general regarding the quality of justice.

The media has emphasized the low credibility of the judicial system through defamatory publications and reports that casts doubt over the conduct of some magistrates and draw a negative image over the entire system.

Magistrates must understand that it is not possible to avoid an external evaluation, as long as the courts will react more effectively to the users' needs the quality of the judicial service and the court's prestige will increase bringing real benefits to all parties.

So, the elements that negatively or positively affect the courts' quality must be brought to the fore, in addition to the process and the decision in itself and the treatment of the parties and the public, the speed of the procedures, the competitive and the staff's professionalism, the organization and the management of solving cases.

Also the current direction requires facile access to the public service, transparency in justice, creating the premises for a friendly climate in the relationship between the courts and the citizens, promptly and effectively solved complaints that relate to services provided to the public.

Furthermore, we consider that measuring satisfaction, knowing the expectations and requirements of the citizens should not be only recorded as a final stage. Judicial organizations should use the citizens' needs and expectations as a starting point to make some suggestions based on customer needs and expectations, respecting also other corporate imperatives.

Therefore the management of satisfaction refers to the management of services and / or products, but also in managing expectations and perceptions of the citizen / customer. Satisfaction measurement it is only one element in this overall satisfaction management. (European Public Administration Network (EUPAN).

\footnotetext{
1 Source: European public administration network
} 


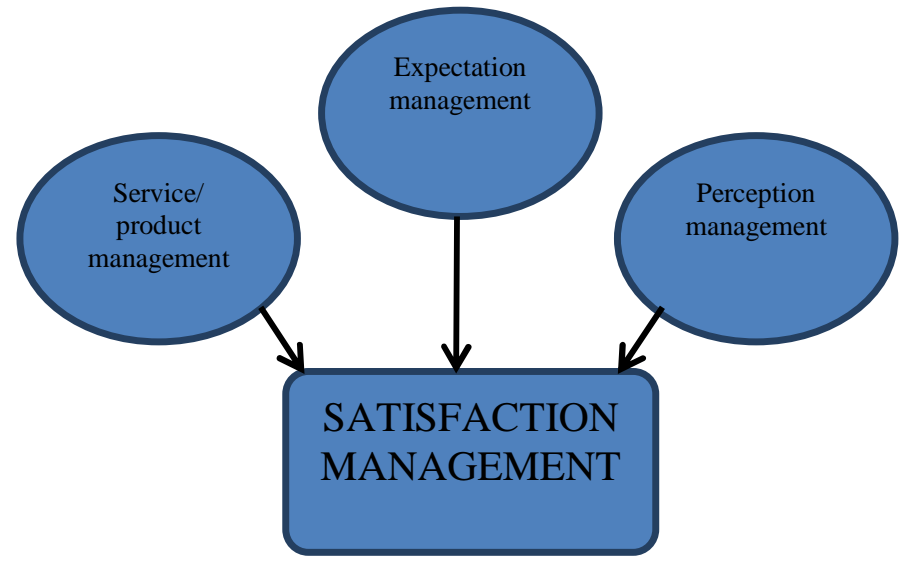

Figure 2: Satisfaction Management ${ }^{2}$

Courts must evolve from a closed and egocentric service provider to a type of an open network organization in which the public can trust. This goal requires respect for citizens, to accept external feed-back, transparency and accountability.

Measuring the customer's satisfaction is therefore an indispensable element for the public organizations enabling the validation that they do the right thing. The position of public institution it is not always easy because of the customer's nature on the one hand and the public on the other. Citizens / customers present different aspects and different roles; sometimes they are the customers of the service and sometimes they behave like citizens, especially when they have to pay taxes or comply with some rules (Ministers' Cabinet, 2006)

Current directions demand a democratic dialogue, from an internal source (resources and activities) to an external source (effect and result); from a classic cycle design-decisionproduction-evaluation to stakeholder's involvement in general and also a democratic dialog especially with the citizens (as customers) at each stage of this cycle. (European Public Administration Network (EUPAN).

Citizens / customers become co-designers, co-deciders, coproducers and co-evaluators. These guidelines, as the result of a joint effort of the public administration from everywhere in order to find the best solutions for current requirements, must become guiding principles applicable in every branch of Romanian public sector adapted to each specific activity and institution. The judicial system should become a promoter of some quality services adapted to the citizens' needs.

\section{FROM DESIGN TO CO-DESIGN}

Design phase of innovations for the service provided for the citizens it is a crucial stage of applying the quality management's principles in this sector. This step will set the opening directions for operational "production" of the services and evaluating the innovations and services in themselves.

One of the main responsibilities of management it is to create and communicate an open attitude, supportive to improvement suggestions, no matter where they originate from.

Another aspect is that the design process of innovation in itself for complying the judicial organizations' services with the public needs should be complete and also clearly define all stages, how it will be implemented and it will be evaluated the change brought, the novelty.
In the first stage, the suggestions can come from anywhere, from people inside the professional organizations, the closest individuals to the courts, lawyers, experts, interpreters and of course the citizens as clients of the judicial services. It is vital that the design phase to include a wide range of opinions and stakeholders in its early development.

The design phase services should not be one in which only a few people from inside the organization conceive all the plans, and afterwards seeks consultation.

"Start as you mean to go on" as the English saying goes, if the services innovation involve staff or user participation, that input must be sought from the design stage.

As mentioned above, another important aspect is designing the process of innovation as complete as possible, should not be provided only the decision and production stages, but also the evaluation stage.

For an evaluation process not to become an artificial stage should be given more attention in the initial stage and not when it is already in the course of implementation and adapting it during. Evaluations can be much improved paying attention from an early stage, involving a wide range of stakeholders, establishing exactly what the staff should understand from the evaluation and what users should learn.

During the shift from design to co-design, organizations do not claim to be the only ones to know the world and hold the truth. The needs and expectations are retained to be taken into account when designing services /products, knowing how to be provided, design the processes, offering information.

\section{FROM DECISION TO CO-DECISION}

Co-decision should be seen as a prerequisite for the sustainability of quality because the citizens / customers come to consider themselves a share in decisions taking.

The result of the professional activities chain performed by all the members of the court - the way it is perceived how different sectors designed for the public, how the information is organized regarding the ongoing trials, case law, etc. - it is determined by the level of interest that judicial managers manifest about what discontents the public in functioning of a courts and their involvement in correcting the situations that may affect the court's activity and the public perception of it. (Alexandrina, R.)

In the case of the judicial organizations, unlike other areas of the public sector, involving the citizens in decision making process, deal with some limitations due to the specific of the justice activities, their independence. Examples such as those mentioned by Bouckaert, Loffler and Pollitt (2006) the codecision takes the form of participatory development of the budget as in Porto Alegre; but also in European cities such as Saint Denis, in France or Sevilla, in Spain cannot be admitted in the case of justice being able to seriously affect the imperatives of independence and impartiality.

Instead, citizens / customers can become better informed through the debate that precedes decision taking, this creating more legitimacy.

It is clear that participation can increase satisfaction. An example is the case of Bolzano Prosecutor, institution that started a "pilot project for reorganization and improvement the office" in order to increase administrative efficiency and cost-

\footnotetext{
${ }^{2}$ Source: European public administration network
} 
effectiveness, involving staff and boosting their motivation in the office's life. (www.procura.bz.it. )

The main approach was to set the location of the Prosecutor namely achieving the comprehensive perspective about the dense network within which it operates the Procure and the high number of stakeholders who are in contact daily. The parties' scheme interested into Bolzano Procure aims at describing the relationships, measuring the frequency of relations and identifying "key stakeholders" according to the degree of proximity to the Procure rather than the hierarchical criteria.

Another feature of the project was taking into consideration the "language of values" specific, which links the institution of each category of stakeholders. It was considered that each category has its own interest, which means that the dialogue must be monitored and measured by means of specific indicators for each activity carried.

The SWOT analysis was also used to highlight the relationship between each stakeholder and Prosecutor, identifying strengths, weaknesses, opportunities and threats. The project has paid great attention to improving the website, taking into consideration the input and the suggestions from the Prosecutor stakeholders (lawyers, police investigation, police and magistrates in other judicial offices). Regarding the measurement and monitoring the needs of the citizen / user information are attained through systematic collection and processing of complaints / suggestions (received via Internet or directly at the office) and also periodic surveys about the user's satisfaction, sent to some selected target groups: citizens' who came to the office in order to collect the administrative documents and those who interact with the Procure using the web page www.procura.bz.it.

\section{FROM PRODUCTION TO CO - PRODUCTION}

After making a decision regarding the services' innovation the natural step is to produce it and to implement it. The experience shows that in all areas of co-production services, provider-client, increases the durability of quality because the production and supply becomes more visible and thus more comprehensible and more legitimate.

Co-production is a complex term, because it implies a permanent or temporary involvement of different actors in different stages of a complex production cycle. Co-producing is a sine qua non condition (prerequisite) for a sustainable public sector in general and for some service supply in particular.

In the field of justice organizations the actors involved in coproducing may include, in addition to citizens as customers of judicial services and the specialists in the field, lawyers, and experts.

These opinions were materialized in practice through pilot projects that aim to offer a new perspective on the current need of quality, enhancement of the professional development and activity reporting to citizen's needs. Alexandrina Radulescu describes a first project developed in Cluj, the participants were judges, members of the Association of Magistrates in Romania - Cluj Branch and lawyers from the Cluj Bar Association. As the author mentions, was intended that the first external feedback on the judges' performance to be offered by the specialists closest to the courts. The lawyer is the person with which the case judge should interact more easily from the perspective of using the professional language, partnership which should be played during the resolution of a case. (Radulescu, A.)

The stages are not easy to be fulfilled but we consider these initiatives encouraging and the dialogue about the quality needs interprofessional collaboration, visions and different perspectives that afterwards the quality inside the courts to be experienced at a higher level.

\section{FROM EVALUATION TO CO- EVALUATION}

The final stage in the development of the overall satisfaction management it is involving the citizen / customer in the evaluation stage.

As we have mentioned, we observed that assessing the customer's satisfaction through dialogue and opinion polls are commonly used in most judicial systems in Europe, the stakeholders, citizens as customers but also other categories of specialists in the field of law periodically offering feedback about their position regarding the services provided by the court. Judicial organizations in Romania must adopt these good practices. The only information collected and processed by the system through the Statistics Office of the Human Resources Department and Management of CSM are related to various aspects of the judicial system' activity, such as the number of cases solved by courts and prosecutors, the management of the human resources, openings in courts and prosecutors' offices and the actual workload per judge / prosecutor compared with the national average of the workload per judge / prosecutor. These data are insufficient, and are not able to offer a complete picture of the effectiveness and efficiency of justice, being absolutely necessary to assess the quality, not only through the objective data of performance, but also through the perceptions of the service users.

As the citizens become more aware and want to be better informed, there will be recorded an increasing pressure on the public organizations in order to accept the citizens and the interest groups as co-evaluators. Clearly, the availability of information about the performance in itself cannot improve the quality. Performance measurement "must be a part of a policy and a culture that welcomes and uses the measurement results in order to evaluate and develop the required quality level and type of values and the organization's objectives " (Gaster and Squires, 2003).

\section{CONCLUSIONS:}

The main challenge for the judicial organizations it is both from the managerial point of view as well as cultural management. Romanian magistrates must understand the importance of external feed-back from the justice services' users; to analyze and apply the good practices collected from the European judicial systems which recorded high performances and the judicial managers must assume the difficult task of implementing appropriate strategies for the citizen and change the courts' organizational culture by changing the traditional benchmarks. The act of justice and its product, the court's decision, should not be the only priority but must be given the appropriate importance to treatment of the parties, the satisfaction of the justice's customer.

A real challenge for the judicial managers should be not so much the ability to use the measurement and evaluation tools, but the ability to put into action the information collected by these methods. This means that the organization is willing to 
use such information. So, before choosing the best instrument (s) for measuring the customer's satisfaction should be pointed out clearly and incorporated in the broader concept- the satisfaction management.

\section{ACKNOWLEDGEMENTS}

This work was possible with the financial support of European Social Fund, Operational Programme Human Resources Development 2007 - 2013, Priority no. 1 "Education and training in support for growth and development of the knowledge society", Key Area of Intervention 1.5 "Doctoral and post-doctoral research support" Title: "MINERVA Cooperation for elite career in $\mathrm{PhD}$ and post doctoral research", ID POSDRU 159/1.5/S/137832.

\section{REFERENCES}

1. Apostu, F., Contribuţii la aplicarea unui nou management operaţional în sistemul judiciar românesc, Sibiu, 2009;

2. Cabinetul Miniştrilor, Înţelegerea clienţilor în sectorul public: Un "Manual", Londra, 2006;

3. Chevallier, J. 2005, Le service public, Presses Universitaires de France, Paris, 2005;

4. Cluzel-Metayer, L., Le service public et l'exigence de qualité, Nouvelle Bibliothèque de thèses. Dalloz, 2006;

5. ENCJ - Raportul grupuluide lucru "managementul calităţii”, capitolul 1, disponibil pe http://www.alexandrina-radulescu-csm.ro/docs/evaluareacalitatii-in-justitie.pdf;
6. Gaster, L. şi Squires A. Asigurarea calităţii în sectorul public. Maidenhead: Open University Press, 2003, p. 292;

7. Löffler E. şi Pollitt C. , Scientific report on the 4th European Quality Conference (Raport ştiinţific despre cea de-a 4-a Conferinţă Europeană pe teme de Calitate), Finlanda: Tampere.2006;

8. Pollitt C. şi Bouckaert,G., Îmbunătăţirea Calităţii în Serviciile Publice din Europa, Concepte, Cazuri şi Comentarii. Londra: Sage, 1995;

9. Pupăzan, M.C., The level of customer satisfaction-measure of social efficiency, Annals of the „Constantin Brâncuşi” University of Târgu Jiu, Economy Series, Special Issue/2014- Information society and sustainable development;

10. Reţeaua Administraţiilor Publice Europene (EUPAN), Indreptar European asupra Managementului Satisfacţiei Clientului, disponibil pe http://www.eupan.eu ;

11. Rădulescu, A., - Calitatea in justiţie. Perspective asupra managementului calităţii în instanţe, Casa Cărţii de Ştiinţă, Cluj-Napoca, 2008;

12. Rădulescu, A.,- Paşi către managementul calităţii în justiţie, disponibil pe www.alexandrina-radulescu-csm.ro;

13. Warin, P., La performance publique : attentes des usagers et réponses des ministères, Politiques et Management Public, 17, nr2.,1999;

14. http://www.eupan.eu;

15. http://ec.europa.eu/civil_service/audience/nat_admin/epan _en.htm;

16. www.procura.bz.it.; 